
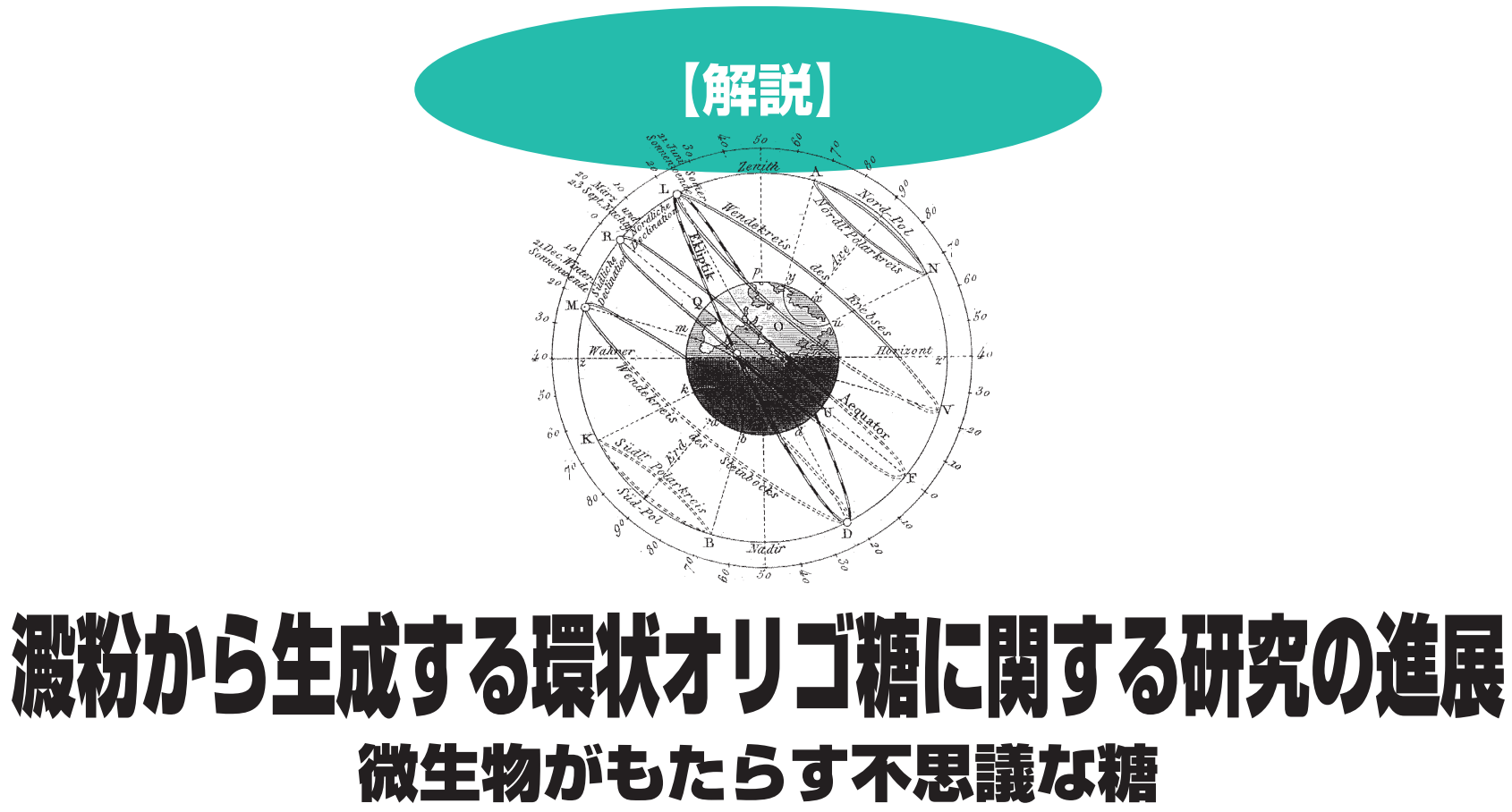

\title{
河野正樹，森 哲也，西本友之
}

\begin{abstract}
シクロデキストリンの発見からおよそ 100 年の時を経て, 2000 年以降, 澱粉から酵素合成される 3 種の環状オリゴ糖が 見出された. 環状オリゴ糖は, 還元性をもたないことから化 学的安定性に優れ, 酵素分解に対しても抵抗性を示すことか ら, 一つの素材として多様な可能性を秘めている. 一方, 環 状オリゴ糖の生成や代謝に関与する醳素は新規な活性を示す ことから，その触媒作用/メカニズムや酵素を活用したモノ づくりに興味が持たれる. シクロデキストリンと同様に, 3 種の環状オリゴ糖についても様々なアプローチが行われ, 多 くの知見が蓄積されつつある. 今後, 澱粉だけでなく各種多 糖から生成する新規環状糖質, 新規酵素の発見も期待できる だろう.
\end{abstract}

はじめに

環状糖はその名のとおりいくつかの糖が環状に連なっ た非還元性の糖である，その歴史は古く，1903年にF. Schardingerによって報告された6〜8個のグルコースが $\alpha-1,4$ 結合によって環状化したシクロデキストリン

Development of Research on Cyclic Oligosaccharides Derived from Starch: Mysterious Saccharides Created by Microorganisms Masaki KOHNO, Tetsuya MORI, Tomoyuki NISHIMOTO, 株式 会社林原研究部門
（CD）が最初である ${ }^{(1)}$ 。この報告からすでに 110 年以上 経過し, CD 以外にも数多くの環状糖の存在が明らかと なっている。過去，本誌に2006年現在までに報告され た 15 種類の環状糖をまとめている(2).

本解説では, 近年研究が進んでいる澱粉から酵素的に 合成可能な $\mathrm{CD}$ 以外の 3 種の環状オリゴ糖，環状四糖 (環状 $\alpha-1,6-$ ニゲロシルニゲロース ; CNN, 環状 $\alpha-1,6$ - マ ルトシルマルトース；CMM）抢よび環状五糖（イソサ イクロマルトペンタオース；ICG5）について, 合成法, 物性㧍よび生理機能, 関連酵素の立体構造などにおける これまでの研究結果に加えて, 2006年以降進展が見ら れた部分について紹介する.

なお，2002年以降，上記環状オリゴ糖に関する総説 が公開されてきた，重複する内容もあるが，全容を把握 するうえで随時参考にしていただきたい(2 10).

\section{CNN, CMMおよびICG5生成機構と物理化学的特性}

澱粉は比較的安価であることからさまざまな有用糖質 の原料として利用されている。その一つの流れとして, 糖質関連酵素の特異的な分解, 転移反応を活用したオリ 


\section{$\bowtie$ ラム $\bowtie$}

澱粉から酵素合成される環状オリゴ糖と言えば, 誰もがシクロデキストリン（CD）を思い浮かべるだ ろう。拈よそ 110 年前に発見されて以来多くの研究が 積み重ねられ，今や重合度の異なる 3 種のCDが食 品, 化粧品, 医薬品分野で活用されている. その後 長い年月を経て，澱粉由来の新たな環状オリゴ糖が 相次いで見いだされた。新しい糖質の発見は，新し い酵素の発見とほほ同義である。実際，これらオリゴ 糖の合成には新規酵素が関与していた。 それぞれ遺 伝子構造が解析され, 輸送や分解に関与するタンパ ク質の同定, 結晶構造解析へと研究は広がっている.

そもそも何故, $\mathrm{CD}$ から新たな環状オリゴ糖の発見 まで 100 年以上もの時間を要したのであろうか? 1990年代に入り澱粉に作用する新規酵素に関する報 告は停滞気味となり，もはや新しい酵素は存在しない のではないかとの雲囲気に満ちていたように思われ る. 探そうとしないのでは，見つかるはずもない. ところが,「新規酵素探索」を掲げて取り組んだ結果, 僅かな時間で新規トレハロース生成系を見いだすこ とができた。この体験を糧にしたさらなる探索が, 一連の新規環状オリゴ糖および新規糖質関連酵素の
発見につながった.

新規糖質/新規酵素の発見は確実に学術的な成果を もたらす。しかしながら，産業化は不確実である。 $\mathrm{CD}$ は疎水的環境を有する内部に包接する能力を活用 し，さまざまな用途に利用されている，新規環状才 リゴ糖も同様の機能が期待されたが，CDに比べ分子 サイズが小さいことから有用な包接機能は認められ ていない，産業化のためには，低コスト製造方法の 開発はもちろんのこと, 用途開発も必須となる。さ まざまなアプローチによる機能探索が現在も継続さ れている。一連の新規環状オリゴ糖が世の中に役立 つことが来る日を待ち望んでいる.

有用酵素探索のターゲットは今や遺伝子が中心と なっているように思われる，しかしながら，遺伝子 配列から，その触媒作用や反応生成物の構造を正確 に推定するまでには至っていない。本稿でまとめた 環状オリゴ糖いずれも土壤微生物の培養液を澱粉に 作用させるというスキームから見いだされた経緯を 考えると，今暫くは土㙵微生物を舞台としたトレ ジャーハンターが活躍できる余地は十分にある。そ うして得られた新規酵素に関する知見は，構造と活 性の相関性に新たな情報をもたらし，広く糖質関連 酵素研究の進展に寄与するだろう。

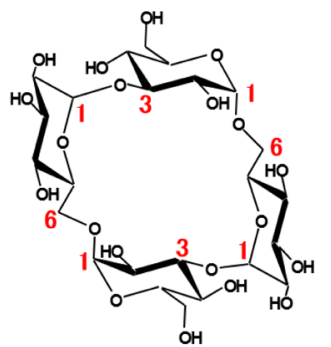

CNN

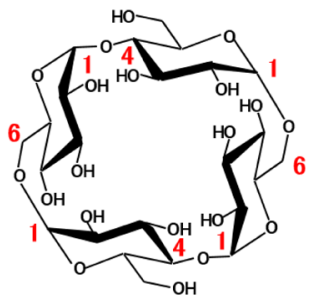

CMM

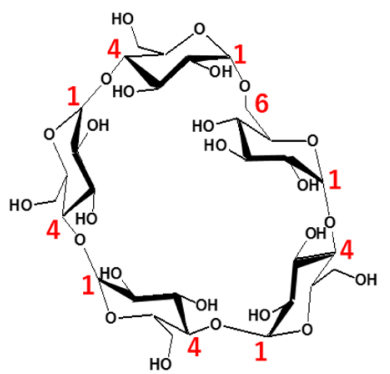

ICG5
図 1・環状四糖および五糖の構造式
ゴ糖の開発が試みられてきた。われわれも土䁃由来細菌 を中心に新規酵素のスクリーニングを継続し，澱粉から のトレハロース生合成系の発見（1995年）につながっ た，その後の成果として，澱粉から酵素合成される環状 オリゴ糖としてCNN, CMMおよびICG5の順に見いだ した。これらの環状オリゴ糖の構造図を図1に示す。い ずれも新規生合成系ではあるが，CNNのみ1994年Côté らにより異なる合成系で生成することが報告されてい た (11). CMMおよびICG5 は新規糖質であった。

以下 $\mathrm{CNN}, \mathrm{CMM}$ およびICG5の生成機構について簡 単に紹介する。詳細な生成機構および関連酵素について は，各項目に記載した論文をご参照いただきたい。ま た，本解説で頻出する糖質の模式図を図2に示している
ので，適宜ご参照いただきたい．

\section{1. $\mathrm{CNN}$ の生成機構}

環状 $\alpha-1,6$-ニゲロシルニゲロース (CNN, cyclo- $\{\rightarrow 6)$ $\alpha$-D-Glc $p$ - $(1 \rightarrow 3)-\alpha$-D-Glc $p$ - $(1 \rightarrow 6)-\alpha$-D-Glc $p$ - $(1 \rightarrow 3)-\alpha$-D-Glc $p$ $(1 \rightarrow\})$ は, Bacillus globisporus や Arthrobacter globiformisの培養上清中に存在する 2 種類の酔素, $6-O-\alpha-ク ゙ ル$ コシルトランスフェラーゼ（6GT）および3-O- $\alpha$-イソマ ルトシルトランスフェラーゼ (IMT) による3段階の分 子間抢よび分子内転移によって生成することがわかって いる(12,13) (図3).

6GTは, 重合度が 3 以上の $\alpha-1,4-$ グルカンの非還元末

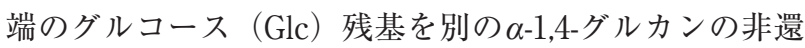




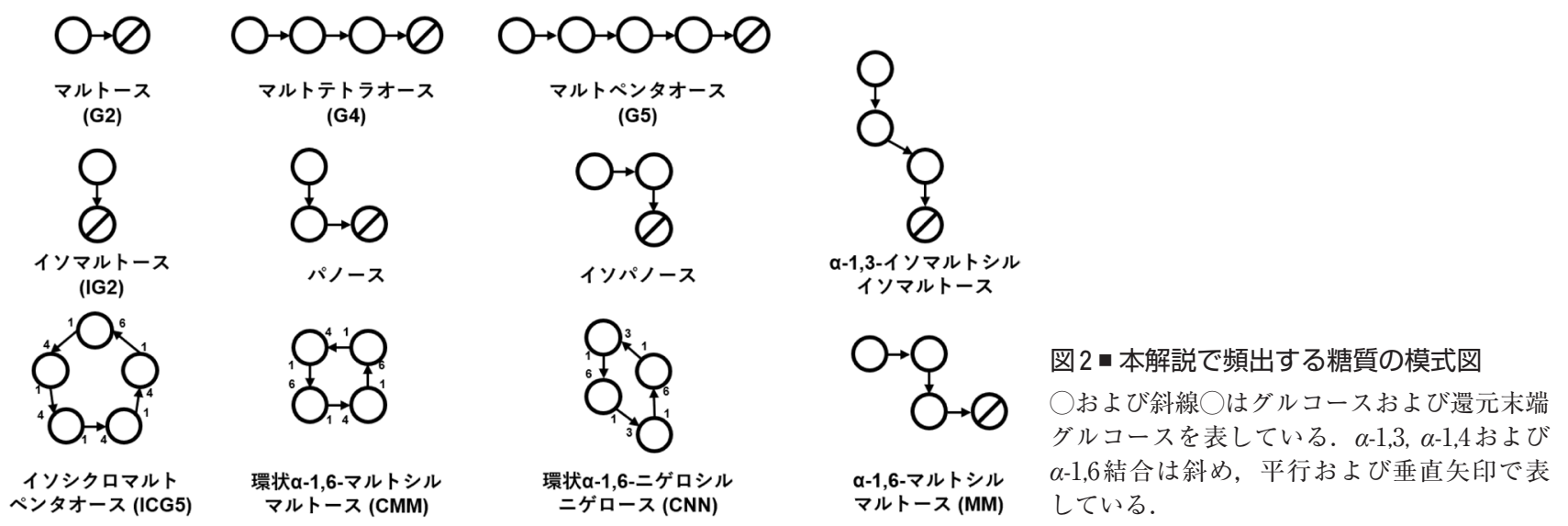

STEP1

OtOJO OEOHO

a-1,4-グルカン (重合度 : $n+2)$

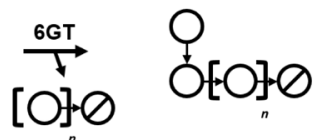

$\mathrm{a}-$ イソマルトシル-a-1,4-
グルカン $($ 重合度 $: \mathrm{n}+3)$

STEP2

0

ÓEOHØ

ÓOTHO

STEP3
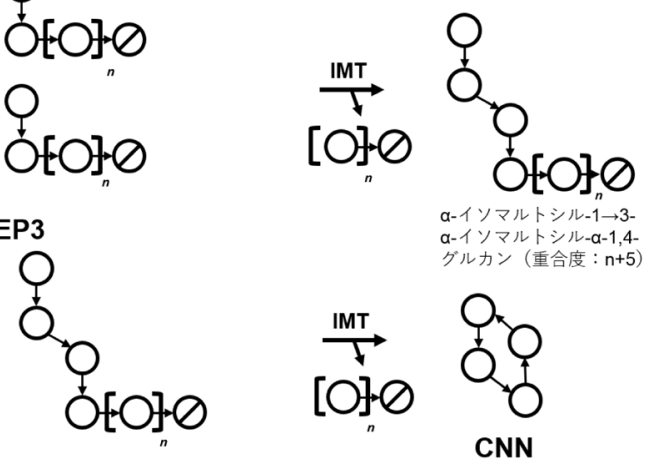

図 3 - $\alpha-1,4$-グルカンからの CNN生成機構の模式図

模式図は図 2 と同様に表している.

元末端に分子間 $\alpha-1,6$ 転移させることにより, 転移され

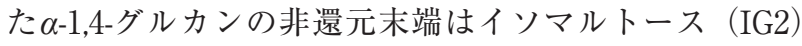
が $\alpha-1,4$ 結合でつながった 4-O- $\alpha$-イソマルトシル- $\alpha-1,4-ク ゙$ ルカンとなる. IMT は生成したIG2残基をほかの 4-O- $\alpha$ イソマルトシル残基に $\alpha-1,3$ 分子間転移するとともに分 子内で $\alpha-1,3$ 転移を行うことにより環状化し, Glc 4 分子 が $\alpha-1,3$ 結合と $\alpha-1,6$ 結合を交互に繰り返した構造を有す る CNNを生成する.

なお，CNNを最初に報告したCôtéらは本糖質をcyclic tetrasaccharide (CTS) \&しくはcycloaltanan （CA）と呼称しているが，後に発見された同じく環状四 糖である CMMと区別するため, われわれはCNNを使 用している.
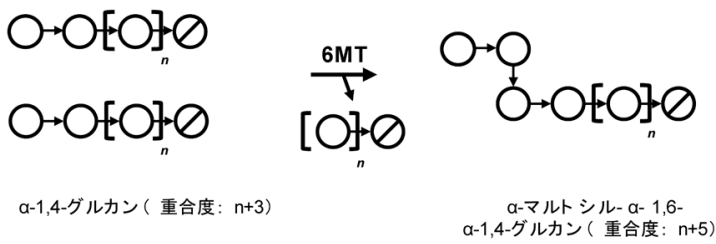

STEP2

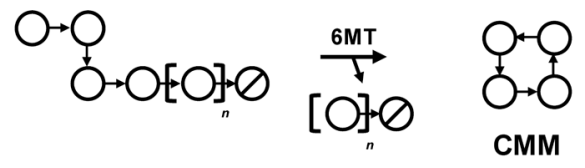

図 4 - $\alpha-1,4-$ グルカンからのCMM生成機構の模式図 模式図は図 2 と同様に表している.

\section{CMMの生成機構}

環状 $\alpha-1,6$-マルトシルマルトース (CMM, cyclo- $\{\rightarrow 6)$ $\alpha$-D-Glc $p$ - $(1 \rightarrow 4)-\alpha$-D-Glc $p$ - $(1 \rightarrow 6)-\alpha$-D-Glc $p$ - $(1 \rightarrow 4)-\alpha$-DGlcp-(1 $\rightarrow\})$ はA. globiformis M6株の培養上清中に存 在する酵素，6- $\alpha$-マルトシルトランスフェラーゼ（6$\alpha$-maltosyltransferase; $6 \mathrm{MT}, \mathrm{EC}$ 3.2.1.-）が触媒する2段 階の分子間㧍よび分子内転移反応によって, 澱粉から生 成されることがわかっている(14,15) (図4).

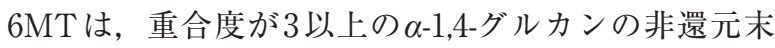

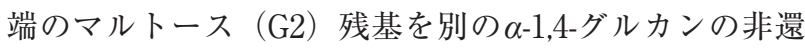
元末端に分子間 $\alpha-1,6$ 転移させることにより， $\alpha-1,4$-グル カンの非還元末端に $\mathrm{G} 2$ が $\alpha-1,6$ 結合でつながった $\alpha$-マル

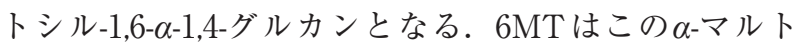
シル-1,6- $\alpha-1,4-$ グルカンの $\alpha$-マルトシル-1,6-マルトース残 基を分子内 $\alpha-1,6$ 転移反応により 環状化することで, Glc 4 分子が $\alpha-1,4$ 結合と $\alpha-1,6$ 結合を交互に繰り返した構造 を有する CMMを生成する. 


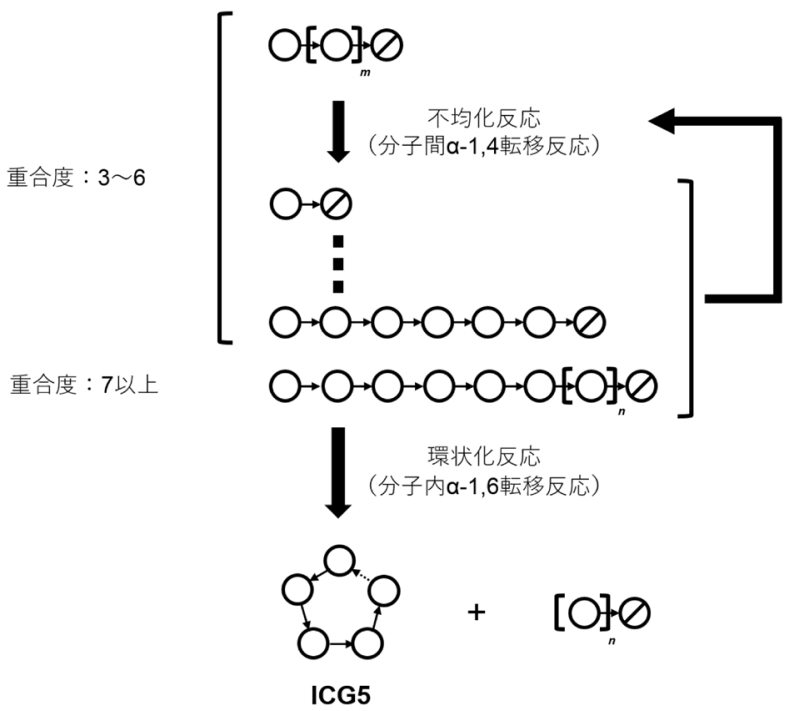

図 5 •マルトオリゴ糖からのICG5生成機構の模式図

実線は $\alpha-1,4$ 結合を，破線は $\alpha-1,6$ 結合を表している.

\section{ICG5 の生成機構}

澱粉から環状糖を合成する酵素生産菌を探索する一連 の研究で, 土壤から単離したB. circulans AM7が，マ ルトペンタオースが $\alpha-1,6$ 結合により環状化した構造を している isocyclomaltopentaose (ICG5; cyclo- $\{\rightarrow 6$ ) $\alpha$-D-Glc $p$ - ( $1 \rightarrow 4)$ - $\alpha$-D-Glc $p$ - $(1 \rightarrow 4)-\alpha$-D-Glc $p$ - $(1 \rightarrow 4)$ - $\alpha$-D$\mathrm{Glc} p-(1 \rightarrow 4)-\alpha-\mathrm{D}-\mathrm{Gl} \mathrm{c} p-(1 \rightarrow\})$ を生成することを 2006 年に 見いだした ${ }^{(16)}$.

B. circulans AM7 の培養上清から, 種々のクロマト グラフィーを経て ICG5生成酥素を精製した，本精製醳 素を Glc 残基 7 分子が $\alpha-1,4$ 結合で結合したマルトヘプタ オースに作用させることで作用メカニズムを解析したと ころ, 本酵素はマルトオリゴ糖単位で分子間 $\alpha-1,4$ 転移 反応を触媒することでさまざまな重合度のマルトオリゴ 糖を生成する（不均化反応）とともに，非還元末端から マルトペンタオース単位で $\alpha-1,4$ 結合を切断し，分子内 $\alpha-1,6$ 転移反応を触媒することにより ICG5 を生成する新 規な糖転移酵素であることがわかり，本酥素をisocyclomaltooligosaccharide glucanotransferase (IGTase) と 命名した ${ }^{(17)}$. そのアミノ酸の 1 次配列と触媒機構から glycoside hydrolase familly 13 （GH13）に属する酵素で あることが明らかとなった、マルトオリゴ糖を基質とし たIGTaseによるICG5 の生成メカニズムを図5に示す.

\section{4. 環状糖の物理化学的特性}

本稿にて紹介した環状オリゴ糖の物理化学的特性を 表1にまとめた。これら環状糖は $\mathrm{pH}$ や熱に対して安定 で，非還元性であることからメイラード反応をほとんど

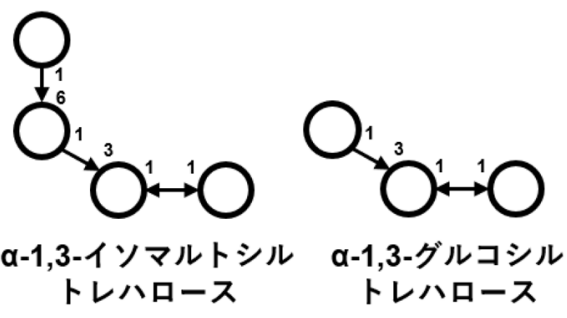

図6・IMTを活用したグリコシルトレ八ロースの酢素合成

○抄よび斜線○はグルコース拉よび還元末端グルコースを表して いる. $\alpha-1,3, \alpha-1,6$ および $\alpha-1,1$ 結合は斜め，垂直拉よび両方向矢印 で表している.

起こさないなどの特徴を有している.

\section{CNNに関する研究の進展}

\section{CNNの生成に関与する酵素の活用}

1.1 IMT 活用したグリコシルトレハロースの酵素合成

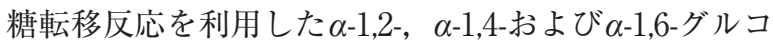
シルトレハロースの酵素合成については報告されてい た ${ }^{18 \sim 21)}$. IMT はイソマルトシル基の $\alpha-1,3$ 転移を触媒す

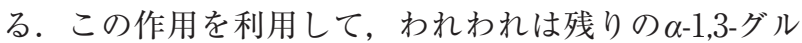
コシルトレハロースの酵素合成を試みた。パノースを供 与体，トレハロースを受容体とした反応液にIMTを作

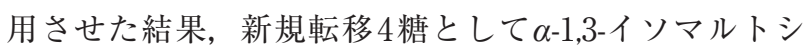
ルトレハロース（図6）が得られた。 さらにグルコアミ

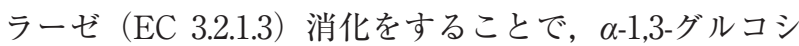
ルトレハロース（図6）の酵素合成に成功した ${ }^{(22) .}$

\subsection{GT を活用したイソマルトースの酵素合成}

6GTをデキストリンに作用させると，非還元末端に IG2構造を生成することができる。この作用を利用して イソマルトデキストラナーゼ（EC 3.2.1.94）共存下, IG2 遊離させる反応系を構築した。

20\%澱粉部分分解物を基質に $6 \mathrm{GT}$ ，イソマルトデキ ストラナーゼ，さらにIG2生成率を向上させるためシク ロデキストリングルカノトランスフェラーゼ（CGTase; EC 2.4.1.19）抽びイソアミラーゼ（EC 3.2.1.68）を組 み合わせ，最適化した．グルコアミラーゼ消化後の IG2 生成率は $65 \%$ に達した ${ }^{(23)}$.

\section{2. $\mathrm{CNN}$ 誘導体}

抄扮むね $\mathrm{CD}$ に倣い，各種 $\mathrm{CNN}$ 誘導体の調製や機能 解析が行われている.

\section{1 分岐 CNNの酵素合成}

$\mathrm{CNN}$ 糖化物中から 4-O- $\alpha$-グルコシル CNN お よび3-O- $\alpha-$ イ ソマルトシル CNNが単離されている(24)。これらは, CNN 
表 1『CNN, CMM およびICG5の物理化学的特性

\begin{tabular}{|c|c|c|c|c|}
\hline \multicolumn{2}{|l|}{ 項目 } & $\mathrm{CNN}$ & $\mathrm{CMM}$ & ICG5 \\
\hline \multicolumn{2}{|l|}{ 還元力 } & 非還元性 & 非還元性 & 非還元性 \\
\hline \multicolumn{2}{|l|}{ 比旋光度 } & $+243.4^{\circ}$ & $+207.9^{\circ}$ & $+71.9^{\circ}$ \\
\hline \multirow[t]{3}{*}{ 水に対する溶解度 } & $20^{\circ} \mathrm{C}$ & $46.1 \mathrm{~g} / 100 \mathrm{~g}$ & $7.1 \mathrm{~g} / 100 \mathrm{~g}$ & - \\
\hline & $50^{\circ} \mathrm{C}$ & $74.2 \mathrm{~g} / 100 \mathrm{~g}$ & $10.4 \mathrm{~g} / 100 \mathrm{~g}$ & - \\
\hline & $90^{\circ} \mathrm{C}$ & $191.4 \mathrm{~g} / 100 \mathrm{~g}$ & $25.0 \mathrm{~g} / 100 \mathrm{~g}$ & - \\
\hline \multirow[t]{2}{*}{ 吸湿性 } & 5 含水結晶 & 吸湿しない & 吸湿しない & - \\
\hline & 無水結晶 & RH30\%以上で吸湿 & RH30\%以上で吸湿 & - \\
\hline \multicolumn{2}{|l|}{ ガラス転移温度 } & $242.4^{\circ} \mathrm{C}$ & $238.5^{\circ} \mathrm{C}$ & - \\
\hline \multicolumn{2}{|l|}{ 甘味度 } & 砂糖の $27 \%$ & 砂糖の $20 \%$ & - \\
\hline \multicolumn{2}{|l|}{ 水溶液の $\mathrm{pH}$ 安定性 } & $>99 \%$ 残存 $(\mathrm{p}$ & $\left.3.5-10,100^{\circ} \mathrm{C}, 24 \mathrm{~h}\right)$ & $>99 \%$ 残存 $\left(\mathrm{pH} 5-10,0^{\circ} \mathrm{C}, \mathrm{h}\right)$ \\
\hline \multicolumn{2}{|l|}{ 水溶液の熱安定性 } & \multicolumn{3}{|c|}{$>99 \%$ 残存 $\left(120^{\circ} \mathrm{C}, 90 \mathrm{~min}\right)$} \\
\hline \multicolumn{2}{|c|}{ メイラード反応性（グリシン） } & \multicolumn{3}{|c|}{ 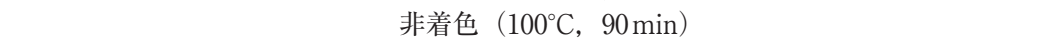 } \\
\hline \multicolumn{2}{|c|}{ メイラード反応性（ポリペプトン） } & \multicolumn{2}{|c|}{ 非着色 $\left(120^{\circ} \mathrm{C}\right.$, in $)$} & ごく僅か有り $\left(120^{\circ} \mathrm{C}, 90 \mathrm{~min}\right)$ \\
\hline
\end{tabular}

\section{表 2 『酵素合成法により調製された分岐 CNN}

\begin{tabular}{|c|c|c|c|}
\hline 分岐 CNN & 使用酵素 & 供与体 & 参考文献 \\
\hline 6-O- $\alpha$-ガラクトシル CNN & $\alpha$-ガラクトシダーゼ & メリビオース & (26) \\
\hline $\begin{array}{l}\text { 4-O- } \alpha-\text { グルコシル CNN } \\
\text { 4-O- } \alpha \text {-ジグルコシル CNN }\end{array}$ & CGTase & $\alpha$-シクロデキストリン & $(27)$ \\
\hline 3-O- $\beta$-N-アセチルグルコサミニル CNN & リゾチーム & N-アセチルキトテトラオース & (28) \\
\hline $\begin{array}{l}3-O-\beta \text {-ガラクトシル CNN } \\
6-O-\beta \text {-ガラクトシル CNN }\end{array}$ & $\beta$-ガラクトシダーゼ & ラクトース & (29) \\
\hline 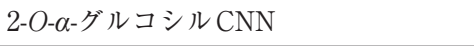 & コージビオースホスホリラーゼ & $\beta$-グルコース1-リン酸 & (30) \\
\hline
\end{tabular}

表 3 - 有機合成法により調製された CNN 誘導体

\begin{tabular}{|c|c|c|}
\hline $\mathrm{CNN}$ 誘導体 & 誘導体化の目的 & 参考文献 \\
\hline ジカルボキシル化誘導体 & 金属イオンとの親和性評価 & $(31)$ \\
\hline アルギン酸誘導体, ポリアクリル酸誘導体 & 生体親和性材料 & $(32)$ \\
\hline ポリスチレン-マレイン酸コポリマー誘導体 & 生体親和性材料 & $(33)$ \\
\hline 硫酸エステル化誘導体 & 抗血栓剂, 抗ウイルス剤 & $(34)$ \\
\hline ポリウレタン誘導体 & 生分解性ポリウレタンフォームの調製 & $(35)$ \\
\hline ジカルボキシル化誘導体 & ラジカル生成抑制剤 & $(36)$ \\
\hline イソフタル酸およびテレフタル酸モノエステル化誘導体 & キラル超分子増感剤 & $(37)$ \\
\hline モノ-およびジ-2-アントラセンカルボン酸エステル化誘導体 & 光環化二量化における光反応性と立体選択性の制御 & $(38)$ \\
\hline ピロメリテート架橋によるナノスポンジ化誘導体 & ナノスポンジの物性評価 & (39) \\
\hline ピロメリテート架橋によるナノスポンジ化誘導体 & 抗ガン剂ナノキャリアとしての評価 & $(40)$ \\
\hline
\end{tabular}

の合成に関与する $6 \mathrm{GT}$ およびIMTが CNNに対して糖転移

反応を触媒することで合成されることが証明されている(25). そのほか，CNNを受容体とした糖転移反応により各種分岐 CNN の酵素合成が試みられている(26 30)（表2）。

\section{2 有機合成による $\mathrm{CNN}$ 誘導体の調製 (31 40)}

CNN の持つ化学的安定性および対称形に注目し，官 能基導入による活性付与やポリマー化の基材としての活 用が期待されている。これまでに報告された事例を表3
にまとめる

\section{3. $\mathrm{CNN}$ の生理機能}

$\mathrm{CNN}$ は各種加水分解酵素に対し高い耐性を有してい る(41)。われわれは，ヒトが摂取した場合，ほとんど血 糖值およびインスリン值に影響しないことを確認してい る。この結果は，CNNが食物繊維素材であることを意 味している. 
A メラ二ン産生量 (14日処理後)

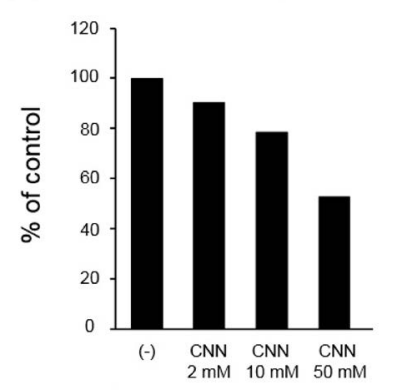

B

$(-)$
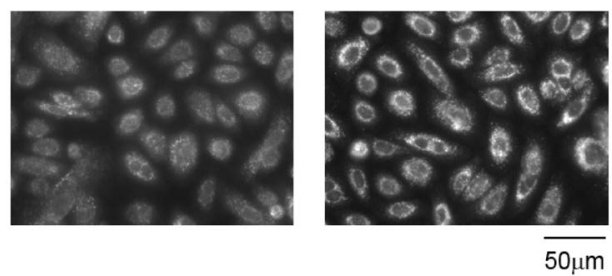

\section{図7ロCNNが示す生理機能}

（A）マウスメラノーマ細胞に対する美白作用. マウスメラノーマ B16を CNN の濃度 2, 10, $50 \mathrm{mM}$ で 14 日間培養した後, 細胞を回収 し産生されたメラニン量を吸光度法にて測定し，タンパク量当た りのメラニン産生量を算出した。左図は無処理群を $100 \%$ とた 時の相対的なメラニン産生量を示した. 右図は細胞を回収した時 の細胞ペレットの様子を示した。（B）正常ヒト皮膚角化細胞に対 するオートファジー誘導作用. オートファジーマーカーである LC3B タンパクの発現を免疫細胞染色法にて観察した. 無処理に 比べCNN処理細胞ではLC3B 陽性のドット（オートファゴゾー ム）の数ならびに強度が促進されている.

In vivoの動物実験結果から, CNNは $\operatorname{IgA}$ 産生促進作 用を有していることが報告されている(42). 1 5\%の CNNを含む餌を与えられたマウスは，瓷便中に含まれ るIgAがコントロールと比較して有意に上昇していた. 特に，5\% CNNのグループでは盲腸内中の $\mathrm{pH}$ が低下 し, 乳酸および酪酸量が増加していた。このような作用 はニゲロオリゴ糖もしくはイソマルトオリゴ糖では観測 されて抢らず，CNNが腸内細菌叢を変化させ，間接的 に腸内免疫機能を高めていると考えられる.

その後, in vitroの実験でマウスメラノーマ細胞に対 する美白作用，すなわちメラニン産生の抑制作用が確認 された (図7A)。この実験では長期培養でCNNが細胞 内に蓄積されるものの, 細胞に対する障害は見られない ことも明らかにされた。また，興味深いことにCNNは さまざまな細胞種に対してトレハロースと同程度のオー トファジー誘導作用を示すことも明らかになってきてお り，オートファジー誘導物質としての利用が期待され る(43) (図7B).

そのほか, 敗血症の予防㧍よび治療剤としての有効性 が報告されていることからも(44), CNNは多様な好まし
い生理機能を有していると言える。

なお，CNNはJoint FAO/WHO Expert Committee on Food Additives（JECFA）の安全性評価を受けている. 1日当たりの摂取量は not specified と認定されており, 高い安全性が確認されている.

\section{4. 他グループによる研究}

2016年に北海道大学のグループは, 放線菌Kribbella flarida $\mathrm{NBRC} 14399^{\mathrm{T}}$ のゲノムに扔いて CNNに関連した 2つのクラスターが存在することを発見し, 詳細な解析 を行っている(45). 一つのクラスターは，これまでにA. globiformis A19などで報告されている6GTおよび $\mathrm{IMT}^{(6)}$ のホモログをコードし, $\mathrm{CNN}$ の生成にかかわる ことを示している.もう一方のクラスターは，A. globiformis A19の IMT と 46.2\%の配列相同性を示す GH31酵 素, GH15酵素と $37 \%$ 程度の配列相同性を示すタンパク 質, $\mathrm{ABC}$ トランスポーター, repressor, open reading frame, kinase（ROK）をコードした6 遺伝子から構成さ れていた。彼らは, GH31酵素の Kfla1985およびGH15 酵素のKfla1986について詳細な酵素学的性質を調べた. その結果, Kfla1985 はCNN 特異的に作用し， $\alpha-1,3$-イソ マルトシルイソマルトースを経由して IG2 生成するこ とから, CNN中の $\alpha-1,3$ 結合を特異的に分解する酵素で あることが明らかとなった。また，2004年に農研機構 のグループらによって報告されている $\mathrm{CNN}$ 分解酵素 ${ }^{(46)}$ と高い配列相同性（約 70\%）を有し, 類似した醉素学 的性質を示すことから，オルソログであると考えられ る。一方, Kfla1986 はIG2を加水分解し Glcを生成した が，G2などのほかの $\alpha$-グルコ二糖には作用しないこと から， $\alpha-1,6$ 結合特異的であることが示された，以上の 結果から, K. flaridaでは菌体外で生成した CNNを ABCトランスポーターによって取り达み, 菌体内に招 いてまずKfla1985がCNNをIG2まで分解し，続いて Kfla1986によって IG2 G Glc まで分解することが示唆さ れた.この報告はCNN分解経路について詳細な酵素学 的解析を行った最初のものである. 加えて彼らは, これ ら遺伝子の発現レベルは対数増殖期に増加し, 実際の $\mathrm{CNN}$ は死滅期に蓄積すること, K. flarida が Glc や G2 と 同等にCNNを炭素源として利用可能であることなど $i n$ vivoでの興味梁い結果を示している.

同年の 2016 年に米国ノースウェスタン大学のグルー プは, Listeria monocytogenes $(\mathrm{Lm})$ の CNN代謝経路 にかかわる酵素・タンパク質について網羅的な構造解析 を行い, 代謝系の全貌について解明している ${ }^{(47)}$. 彼ら が解明したCNN 代謝経路について図8Cに模式的に示し 


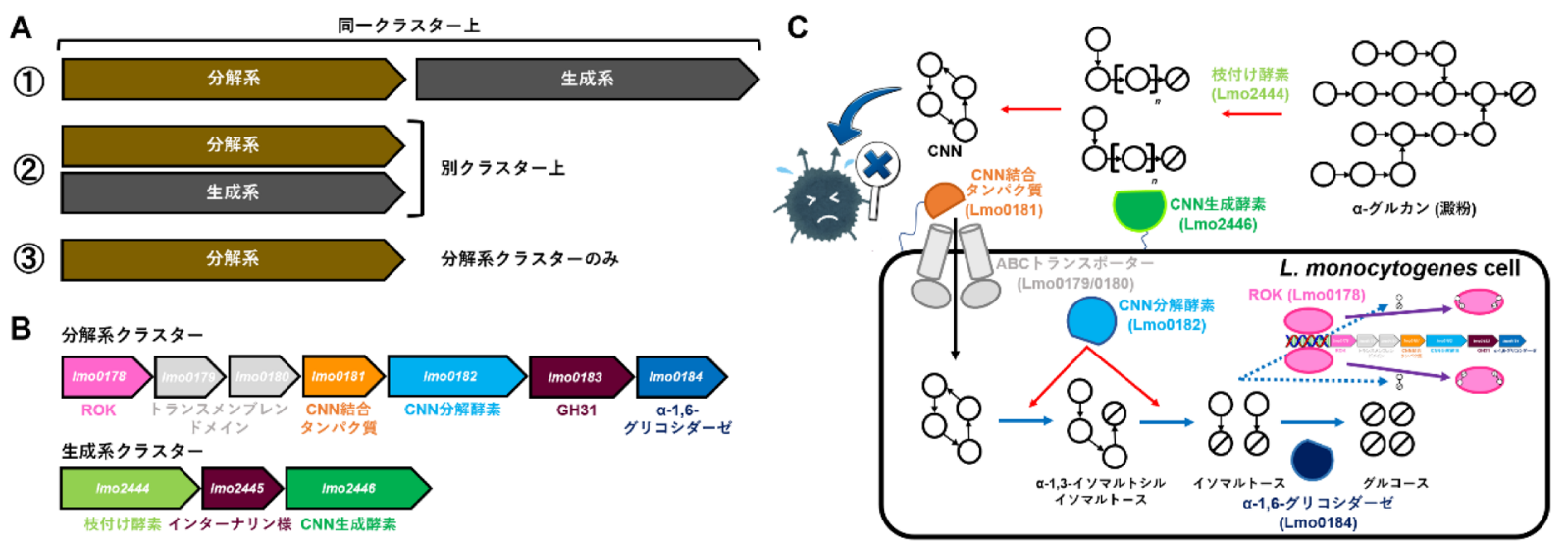

\section{図 8-CNN代謝経路}

(A) 各菌種における3つに分類された CNN関連遺伝子クラスター構造模式図. (B) L L

(C) LmにおけるCNN代謝経路模式図.

た。各菌種における CNN関連クラスターは大きく3つ に分類され, Lmでは上述の K. flarida と同様に生成系 と分解系が別クラスター上に存在する構成であった（図 $8 \mathrm{~A}, \mathrm{~B})$. 生成系は, 推定6GT (Lmo2444) および推定 IMT（Lmo2446）の2つのGH31酵素を含み， $\alpha$-1,6結合 での枝付け拉よびパノースからのCNN生成活性をそれ ぞれ確認している. Lmo2446求核触媒残基変異体とパ ノースとの複合体構造から，パノースの $\alpha-1,4$ 結合部分 が触媒残基付近に位置するような結合様式が確認されて いる. 構造解析からも, IMTは一段階目の反応に抏い て $\alpha-1,4$ 結合を切断し, 非還元末端IG2を非還元末端に $\alpha-1,6$ 結合を含む基質に $\alpha-1,3$ 転移を行うことが推測される (図3)。一方, 分解系は $\mathrm{ABC}$ トランスポーター (Lmo01790181)，2つのGH31酵素 (Lmo0182, Lmo0183)，GH13酵 素（Lmo0184）およびROK（Lmo0178）から構成されて いた，ABCトランスポーターのうち，Lmo0181は高い 親和性 $\left(K_{\mathrm{d}} \bigotimes 2 \mu \mathrm{M}\right)$ で $\mathrm{CNN}$ 特異的に結合する糖質結 合タンパク質であり，その結合様式は CNNの構造に起 因して特徴的であった，GH31酵素であるLmo0182の代 わりとして, オルソログである Trueperella pyogenes 由 来Lmo0182（TpLmo0182）の構造解析が行われた．共 にGH31酵素であるTpLmo0182 およびLmo2446の活性 中心がよく保存されていたことは興味深い。このことか ら，TpLmo0182はLmo2446の逆反応，つまり CNNの 分解を行っていることが推測され, 䤉素学的にもCNN の $\alpha-1,3$ 結合分解性を確認している。 また, 彼らは $T p \mathrm{~L}-$ mo0182 およびLmo2446に扔ける活性部位の高い類似性 から, 転移と加水分解反応のメカニズム解析を行ってい

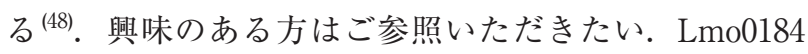
についても構造解析が行われている. 全体構造のみなら

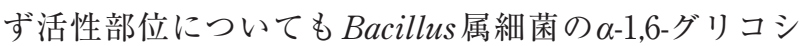
ダーゼとょく似て㧍り, IG2の Glcへの分解活性も確認 されている，以上のことから，このクラスターに存在す る酵素・タンパク質によって取り込みから Glcまでの分 解が行われていることが示された（図8C).さらに, ROK の Lmo0178についての各種解析から, 菌体内での IG2 増加が菌体外における $\mathrm{CNN}$ 存在シグナルとなり, 分解系クラスターの転写抑制が解除されることを示し た。さらに，明らかとなった $\mathrm{CNN}$ 代謝経路の機能につ いてin vivo 実験が行われている，Lmは環境中に広く分 布し, 宿主動物の腸管バリアを超え, 標的臟器細胞内で 増殖することが知られている。、ウスの経口投与実験に おいて，CNNを生成できない $(4 l m o 2446)$ および分解 できない (Almo0182) 株は野生株と比べて任意臟器に おける菌数が約 10 分の 1 であった。ささまざまな炭素源を 用いた培養実験から, CNN代謝経路の生物学的な基質 は腸管における $\alpha$-グルカンであると推測された。さらら に, 液体培養やマウスの経口投与に扔ける野生株との競 合実験においても，両欠損株より野生株の方が増殖性お よび浸潤性が高かった，以上の結果を総合すると， Lm がCNN代謝経路をもつ意義は, 腸管内における宿主を 含めた生物間での限りある炭素源の獲得競争にあると推 測される。つまり， $\alpha$-グルカンを $\mathrm{CNN}$ という特殊な環 状糖に変換することで, CNN 分解遺伝子をもたない菌 や宿主に対して優先的に栄養を得ることができる。この 意義については，ほかの環状糖の代謝経路に対しても当 てはまり，われわれを含めてこれまでに多くの研究者に よって議論されている. 加えて, 環状糖自体が化学的に 安定であり，環境変化による分解を受けにくいという性 質もより一層競争を有利に働かせると考えられる. 

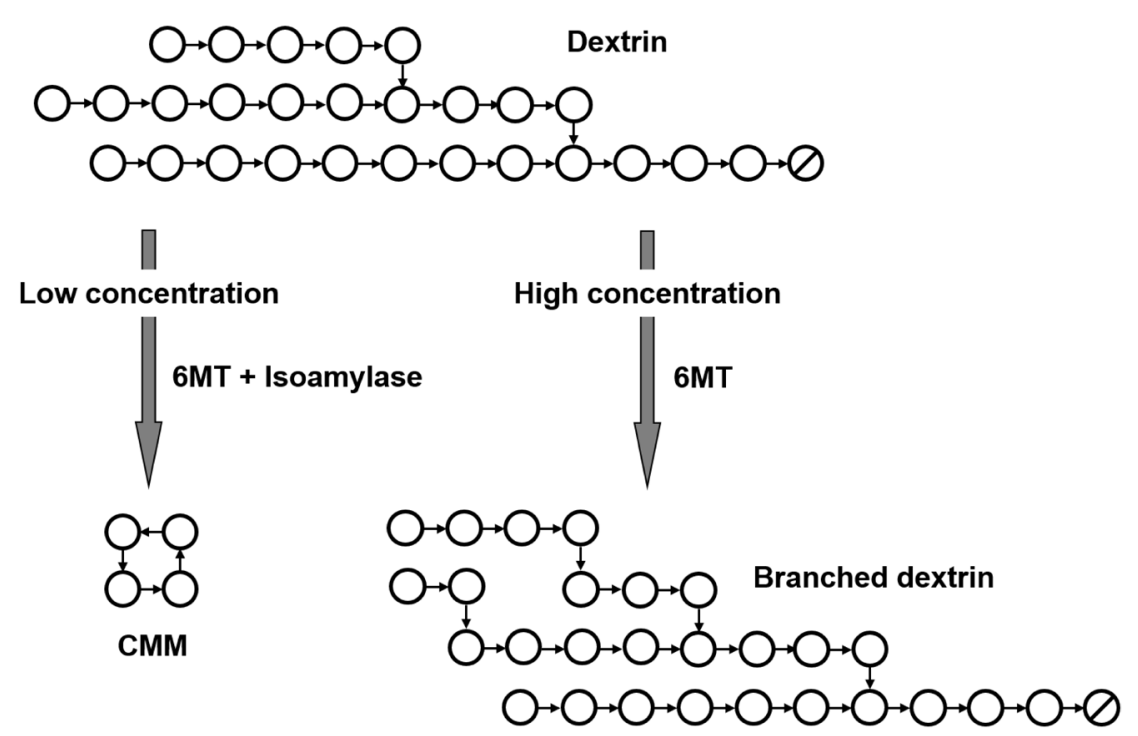

図 9-6MTによる分岐デキストリンの生成

模式図は図 2 と同様に表している.

\section{CMMに関する研究の進展}

1. CMMの生成に関与する酵素の活用 : $6 \mathrm{MT}$ を活用し た分岐構造導入によるデキストリンの老化性抑制

$\mathrm{CMM}$ 生成機構からわかるように, 6MTはマルト シル基単位で $\alpha-1,4$ または $\alpha-1,6$ 転移を触媒する。この分 子間糖転移反応は基質濃度に依存して顕著になる。 反対 に分子内糖転移反応による $\mathrm{CMM}$ 生成は低下する。この 現象は， CD生成反応を触媒するCGTaseでも確認され ている. 比較的高い濃度の高分子ワキシーコーンスター 千部分分解物（平均重量分子量約 100 万）に6MTを作 用させることで非還元性末端に，マルトシル分岐構造を 導入した分岐デキストリンを調製した（図9）。本デキ ストリンは $25 \mathrm{w} / \mathrm{v} \% て ゙ ~ 5 \circ \mathrm{C}, 30$ 日保存しても透明性を維 持していた ${ }^{(49)}$.

\section{2. $\mathrm{CMM}$ 分解酵素の $X$ 線結晶構造解析}

これまでにわれわれは, A. globiformis M6の無細胞 抽出液中から CMMを分解する CMM hydrolase (CMMase, EC 3.2.1.-) を単離し，その酵素学的性質を明らか にしている(50). CMMaseは $\alpha-1,6$-マルトシルマルトース （MM）を経由した 2 段階の $\alpha-1,6$ 結合の加水分解により， CMMを2分子の G2 まで分解する.アミノ酸配列から 6MT と共にGH13に分類された。 さらに, A. globiformis M6におけるCMM関連遺伝子のクローニングによ り, 菌体内へのCMM取り込みに関与する推定 $\mathrm{ABC}$ 卜 ランスポーターの存在が示され，CMMを経由した新規 な澱粉資化経路の存在が見いだされている(51).

CMMase はGH13のサブファミリー20（GH13_20）に 属しており，同じサブファミリーにはThermoactino- myces vulgaris R-47 $\alpha$-amylase (TVAII, EC 3.2.1.135), Geobacillus stearothermophilus neopllulanase (GsNPL, EC 3.2.1.135）などの基質特異性が幅広いものや糖転移 活性を示すような酵素が多く存在している。しかし, CMMase はCMMやその分解産物である MMに非常に 特異的であり, 加水分解しか行わない。 そのため, この 酵素がどのようにCMMを認識し，加水分解を行ってい るのかを調べることは非常に興味深い。そこでわれわれ は, CMMaseのX線結晶構造解析を行い, その基質認 識性を含めた分子メカニズムの解明に取り組んだ(52).

\subsection{CMMase の全体構造}

まず，われわれはCMMaseの基質フリー状態および $\mathrm{G} 2$, パノース， $\mathrm{CMM}$ それぞれとの複合体の結晶構造を 決定した。モノマー構造はGH13 および $\alpha$-amylase関連 酵素において一般的なコア構造である $\mathrm{A}, \mathrm{B}$ およびCの 3 つのドメインから構成され，GH13_20酵素と高い類似 性を示していた（図10B）。

結晶構造中においてCMMaseはドメインC間にて $\beta$ シートを形成し, 非常にユニークな羽型のダイマー構造 を取っていた（図10A）。分子量解析より，CMMaseは 溶液中においてもこのようなダイマー構造を取っている と推測された。われわれの知りうる限りでは，このよう なドメインCを介した羽型のダイマー構造は, GH13酵 素全体においても非常にユニークであり，これまでに報 告されていない. しかし，ダイマー構造において各々の 活性部位は離れているため, ダイマー化は活性に影響を 与えないと考えられる.

2.2 CMMase-基質および生成物複合体構造における活 性部位

基質であるCMMに加えて, 最終分解産物である G2, 

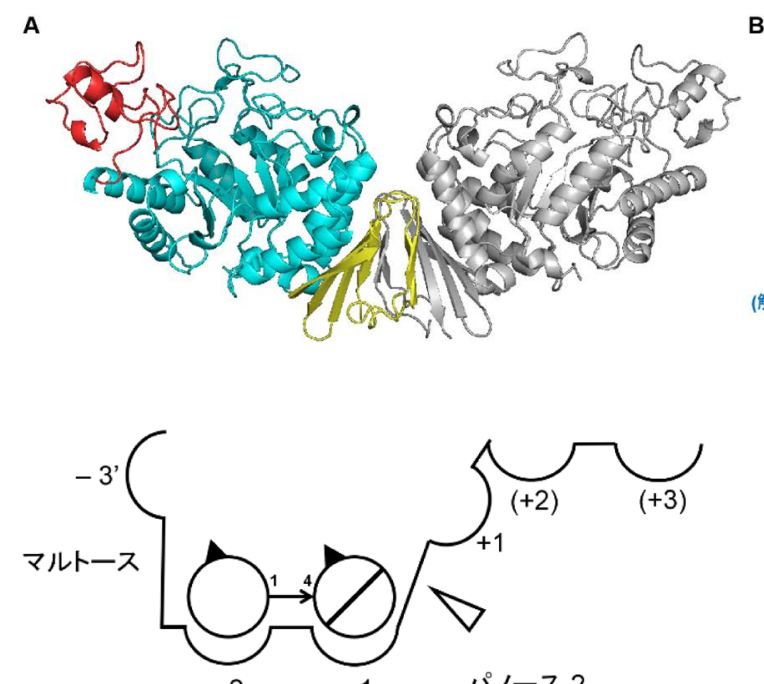

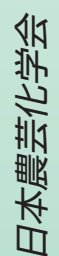
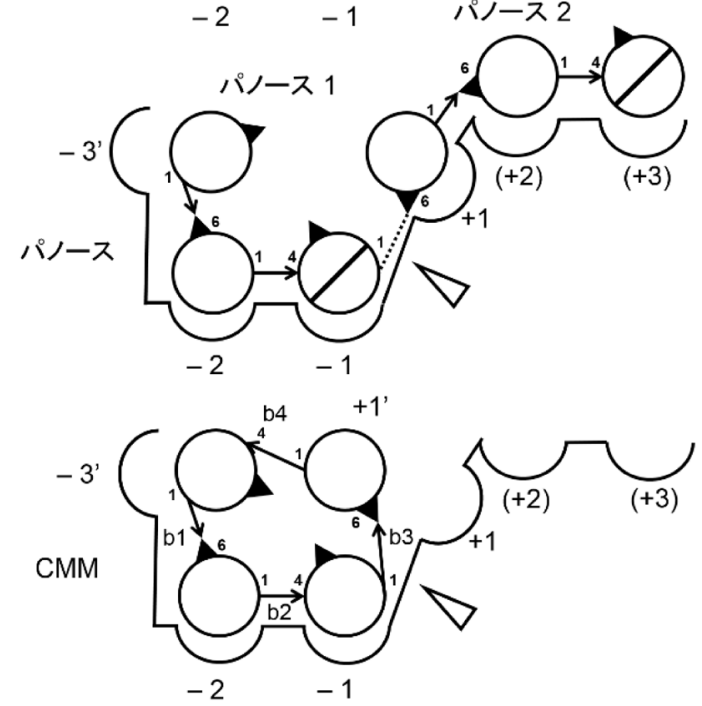

図 11 -CMMase結晶構造の活性部位に対するリガンド結合様 式模式図

○および斜線○はグルコースおよび還元末端グルコースを表して いる．切断部位は三角で示している．矢印はグリコシド結合を表 している. CMMの4つのグリコシド結合はb1〜b4でそれぞれ区 別している.

分解中間産物である MMに部分類似したパノースと CMMase との複合体構造より (図 11)，-3'，-2, および $+1^{\prime}$ と名付けた 4 つの特異的なサブサイトが同定 された。サブサイトー1およびー2はほかの GH13_20醳 素においてもよく保存されているものであった。一方, サブサイト +1'およびー3'はほかの GH13_20酵素とは異 なるCMMase特異的な位置に存在していたことから， 両者ともプライムで表している.

複合体構造の解析から明らかとなった活性部位の構造 的特徵として, CMMase は $\alpha-1,6$ 結合が切断されやすい ようにサブサイト $+1 に$ Glc 部分を結合させるようで あった．加えて，サブサイト -2 から-1には $\mathrm{G} 2$ の強い

\section{図 10 - CMMase結晶構造}

(A) 結晶におけるダイマー構造. (B) CMMase-CMM複合体構造におけるモノマー構 造. CMM分子小よびカルシウムイオンはそ れぞれスティックおよび球で表している.

サブサイトを有している一方，サブサイト $-3^{\prime}$ 抢よび $+1^{\prime} /+1$ の認識性は弱いことである。この特徵は, サブ サイト $+1 に$ 結合する Glc 部分が固定化されている，つ まり $\alpha-1,6$ 結合の摇らぎが少ない基質ほどCMMase は分 解しやすいという基質選択性とも一致している(50)。 ま た，実際にCMMおよびMMに対する動力学的パラメー 夕を測定したところ，CMMに対してより選択的であっ た.

2.3 GH13_20に属するネオプルラナーゼとの活性部位 およびリガンド結合様式の比較

CMMase と同じGH13_20に属しているGsNPL と活性 部位の比較を行ったＧsNPLは $\alpha-1,4$ および $\alpha-1,6$ 結合の どちらに対しても加水分解および糖転移活性を示し，基 質特異性が幅広いユニークな酵素として知られている が(53, 54)，CMMを分解することはできない。両者の高い 配列相同性 (33.8\%) からも予想されたように，これら 酵素の全体構造（モノマー）はよく似ており，図12Bお よび12Dの中心から左側の活性部位残基はよく保存さ れ，逆に右側には違いが認められた。

両者の比較から，それぞれの酵素においてこれらクレ フトの特徵的な壁（wall）の形成にかかわっている残基 は以下のようなグループに分類できた（図 12): CMMaseではPYF（Pro-203, Tyr-204, Phe-205), CS (Cys163, Ser-164） およびY（Tyr-168). GsNPLではANE (Ala-330, Asn-331, Glu-332), FA (Phe-289, Ala-290) およびQ (Gln-294)。PYF/ANEおよびCS/FA wallの 変化によって，CMMaseに㧍けるクレフトの奥行きが なくなった一方，幅は広がっていたままた，Q/Y wall の変化によって, Tyr-168の側鎖がもたらす立体障害が 生まれ，その結果としてCS wallによって形成されるサ ブサイトー3'が上部に位置していた。 以上の結果から， これらのwallにおける変異によって，CMMがぴったり と当てはまるお椀型様の活性クレフトになっていること が明らかとなった。

\section{4 部位特異的変異解析による活性重要残基の特定}

先の結果より, CMM特異性はPYF, CS, Y の3つの wallによってもたらされていると推測された。 そこで, 

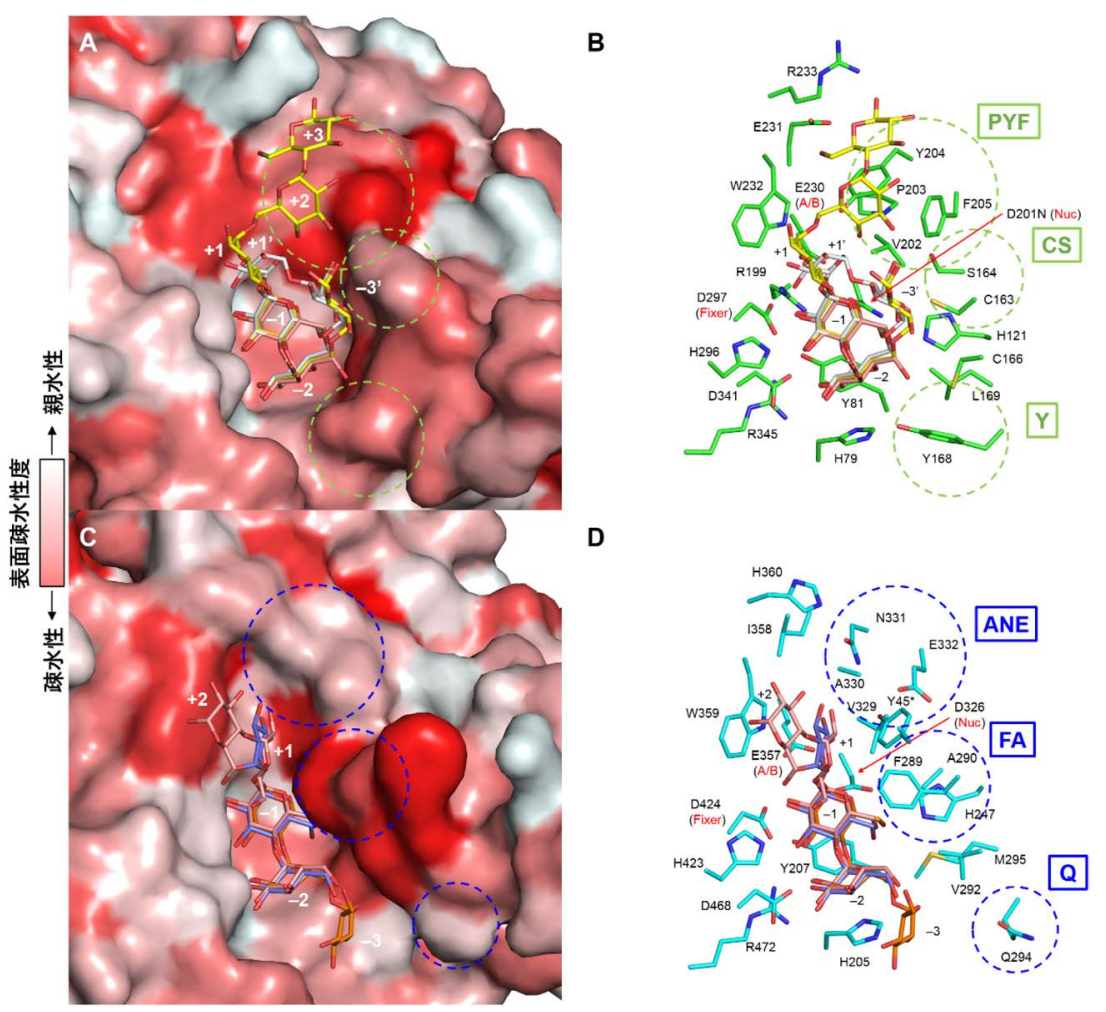

図12・CMMaseおよびGsNPLにおける活 性部位の比較

（A）および（B）；CMMaseの分子表面モデル （A）およびスティックモデル（B)。各複合体 構造由来マルトース，パノース， CMMを CMMase-CMM複合体構造に重ねた。（C）および (D)；GsNPLの分子表面モデル（C）およびス ティックモデル (D). 各複合体構造由来マル トテトラオース (PDB ID: 1J0J), イソパノー ス $(1 \mathrm{~J} 0 \mathrm{~K})$ ，パノース $(1 \mathrm{~J} 0 \mathrm{I})$ をGsNPL-パ ノース複合体構造に重ねた。表面モデルは表 面疎水性度が高い部分を濃い赤色で示してい る.
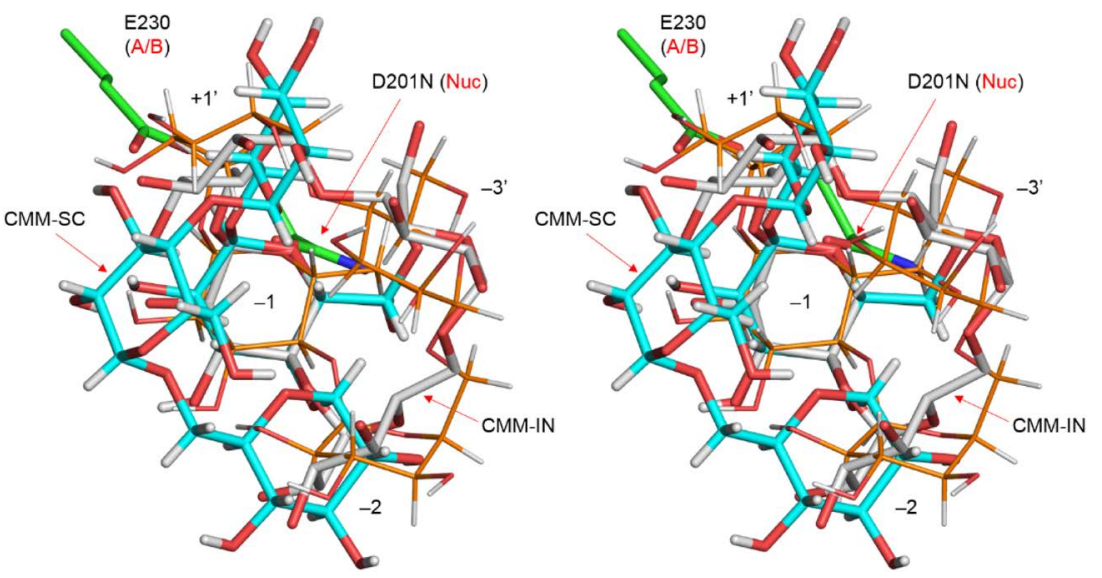

図 13-CMM単結晶 (CMM-SC), CMMase 結合 CMM (CMM-IN) およびエネルギー最 小化CMM分子モデル（CMM-EM）の重ね 合わせ

スティックの細いものはエネルギー最小化構 造として表している. 各 CMM分子はサブサイ トー1に結合している Glc 残基を基準に重ねて いる.

これら残基の活性に対する重要性を明らかにするため, 各wall GsNPLの活性部位に模做した各変異体を作成 し, 解析を行った。各wallにおける一点変異では活性 に著しい影響は観測されなかったが, PYFおよびY wallの変異を組み合わせたところ (Y168Q/P203A/ $\mathrm{Y} 204 \mathrm{~N} / \mathrm{F} 205 \mathrm{E})$, 全変異体間で最も高い $K_{\mathrm{m}}$ 值および最 も低い $k_{\mathrm{cat}} / K_{\mathrm{m}}$ 值を示した。これらの結果は, サブサイ ト -2 および十側において，小さな環状基質に適した CMMaseの捥型クレフトの形成をY抢よびPYF wall が協調して支えていることを示唆している．また，CS wallに扔けるCys-163の各変異では大幅に活性が低下し ていた一方, Valへの変異によって活性が回復してい
た.このことから, Cys-163の疎水性を伴った小さな側 鎖がCMMaseのユニークなサブサイトー 3 ににおける基質 との相互作用に適していると推測された。

\section{$2.5 \mathrm{CMM}$ の構造解析 ${ }^{(52)}$}

続いて, CMMのX線単結晶構造解析を行い, CMMase 結合CMM分子 (CMM-IN) ならびにエネルギー 最小化CMM構造 (CMM-EM) と比較を行った (図 13).CMM-IN と CMM-EMはよく似た構造であるの に対し, CMM 単結晶構造 (CMM-SC) はサブサイト3’の Glcが図13の左側に大きくねじれ，両者と大きく異 なっていた，そこで, 各 $\mathrm{CMM}$ 構造に扔ける各グリコシ ド結合のねじれ角からそのエネルギー状態を確認した。 
その結果，CMM-IN およびCMM-SC の $\alpha-1,6$ 結合（b1 お よびb3）は，両者で大きく異なった構造をとっている ものの高エネルギー配座ではなかった。一方， $\alpha-1,4$ 結 合（b2およびb4）に押いて，CMM-INでは低エネル ギー配座であり, CMM-SCでは極小点から $5 \mathrm{kcal} / \mathrm{mol}$ 以上も高い高エネルギー配座であった，以上の結果か ら，CMMは溶液中においてもいくつかの構造を取るこ とができ，CMMaseには最小エネルギー構造の一つと して結合していることが明らかとなった.

\section{$2.6 \mathrm{CMM}$ 代謝経路について}

CMMaseの構造解析から得られた知見を基にタンパ ク質BLAST検索を行ったところ，3つの wall形成に重 要な残基が基本的に保存されたCMMase ホモログ遺伝 子が多くの菌種のゲノムにも存在していることが示され た。これらのうちで活性が確認されたものは現在のとこ ろないが，推定ホモログはCMMase活性を示し，菌種 としてA. globiformis M6様のCMM代謝経路を有して いると推測された. CMM代謝経路の分子機構をより詳 細に明らかにするためには, CMM の生成㧍よび取り込 みにかかわる醅素・タンパク質についてのさらなる研究 が必要である。

\section{ICG5に関する研究の進展}

B. circulans AM7のゲノムDNAから IGTase 遺伝子 (igt $Y)$ をクローニングした際に，その直下流に機能既 知もしくは機能未知のタンパク質とホモロジーを有さな いタンパク質をコードする遺伝子が存在することを見い だし，igtZと命名した ${ }^{(55)}$.

IgtZ は重合度 4 以上のマルトオリゴ糖や可溶性澱粉に 作用し，グルコースや重合度5までのマルトオリゴ糖を 生成することがわかった，IGTase と IgtZはともに，そ のC末端に生澱粉吸着ドメインを有しており, IGTase と IgtZを同時に生澱粉に作用させることで, IGTase単 独で生澱粉に作用させた場合と比較して効率よくICG5 を生成することがわかった. IgtZは澱粉の $\alpha-1,4$ 結合を 加水分解する $\alpha$-アミラーゼであるが，その新規なアミノ 酸配列から，CAZyにおいて新たな GH Familyが創設さ れ，No.119（GH119）に分類された。現在，酵素的諸性 質が解明された糖質関連酵素のなかで，GH119に分類 されている酵素は，このB. circulans AM7由来IgtZの みである。

また，2012年にスロバキア科学アカデミーのグルー プは, in silico解析から GH57との関連性を見いだし, 触媒ドメイン構造を $(\beta / \alpha)_{7^{-}}$バレル，Glu-231 および
Asp-373をそれぞれ求核触媒抢よび一般酸／塩基触媒残 基との予測を報告した ${ }^{(56)}$. GH119酵素の詳細について 明らかにするため, in vitroに打ける酵素学的解析やX 線結晶構造解析などが待たれる.

\section{おわりに}

澱粉は地球上に豊富に存在する $\alpha$-グルカンである。ま た，澱粉と同じく $\alpha-1,4$ 結合と少量の $\alpha-1,6$ 結合から構成 される $\alpha$-グルカンは生物界に広く分布している. 多くの 生物が澱粉を含め $\alpha$-グルカンを炭素源として利用してい る. 微生物も同じく $\alpha$-グルカンを代謝する仕組みを備え ている.

単純に加水分解するだけでなく, 菌体外で各種環状才 リゴ糖を作り，特有の輸送系で菌体内に取り込む代謝系 の意義はどこにあるのか？ 環状オリゴ糖は非還元性で あることから化学的安定であること, 酥素的にも安定で あることが関係していることは間違いがないが，明確な 回答は得られていない.

一方，環状オリゴ糖は魅力的な物質である．CDにつ いては改めて説明するまでもなく, 多くの機能や活用方 法が報告され，実際に利用されている。ほかの澱粉由来 環状オリゴ糖も今後の活用が期待される，特に，CNN の生成率は糖濃度の影響を受けにくいことから，工業的 製造に対応しやすい。最小の食物瀻維素材である CNN の開発が待たれる.

さらに，環状オリゴ糖の生成に関与する酵素にも興味 はつきない，新しい環状オリゴ糖の発見は，すなわち新 しい酵素の発見を意味している. 各酵素の活用, 触媒機 構に関する研究など，産業および学術に与える影響は大 きい.

なお，澱粉からの環状オリゴ糖生産株はすべて土壤単 離株から見いだされている．ゲノム情報が容易に入手可 能な状況であっても，配列情報からのアプローチだけで はカバーしきれない，依然として，新規性の高い酵素の 探索にはold bioが生かされる領域かもしれない.

今後, 新しい環状オリゴ糖は見つかるであろうか? 構成糖をグルコースに限定したとしても，まだまだ可能 性はあると考えられる。グルカンの代謝機構の中間体と

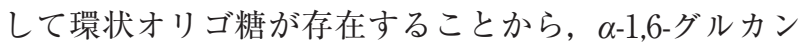

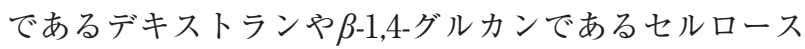
からの探索は十分とは言えない.

デキストランから重合度 5 以下の環状オリゴ糖（シク ロデキストラン）の生成は確認されていない。また，環 状 $\beta$-グルカン /オリゴ糖として, 重合度 $17 \sim 25$ の環状 
$\beta$-1,2-グルカン ${ }^{(57)}$ や重合度 8 の環状 $\beta$-1,3-オリゴ糖 ${ }^{(58)}$ が見 いだされているが，澱粉以上に存在量の多いセルロース

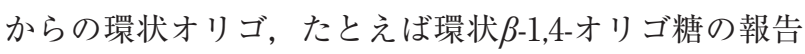
はなく, 存在しないと判断する理由はない.

\section{文献}

1) F. Schardinger: $Z$ Unters Nahr Genussm, 6, 865 (1903).

2) 西本友之, 奥 和之, 向井和久：化学と生物, 44, 539 (2006).

3) T. Nishimoto: Trends Glycosci. Glycotechnol., 14, 321 (2002).

4) T. Nishimoto, H. Aga, M. Kubota, S. Fukuda, M. Kurimoto \& Y. Tsujisaka: J. Appl. Glycosci., 51, 135 (2004).

5) 西本友之：日本農芸化学会誌, 78, 866 (2004).

6) K. Oku \& H. Watanabe: F.F.I. Journal of Japan, 211, 854 (2006).

7) H. Watanabe, T. Nishimoto, H. Chaen \& S. Fukuda: J. Appl. Glycosci., 54, 109 (2007).

8) T. Mori, T. Nishimoto, K. Mukai, H. Watanabe, T. Okura, H. Chaen \& S. Fukuda: J. Appl. Glycosci., 56, 127 (2009).

9) 渡邊 光：日本応用糖質科学会誌, 1, 307 (2011).

10) 河野正樹, 荒川孝俊, 太田弘道, 森 哲也, 西本友之, 牛尾慎平，伏信進矢：日本応用糖質科学会誌，9, 103 (2019).

11) G. L. Côté \& P. Biely: Eur. J. Biochem., 226, 641 (1994).

12) T. Nishimoto, H. Aga, K. Mukai, T. Hashimoto, H. Watanabe, M. Kubota, S. Fukuda, M. Kurimoto \& Y. Tsujisaka: Biosci. Biotechnol. Biochem., 66, 1806 (2002).

13) M. Mukai, K. Maruta, K. Satouchi, M. Kubota, S. Fukuda, M. Kurimoto \& Y. Tsujisaka: Biosci. Biotechnol. Biochem., 68, 2529 (2004).

14) K. Mukai, H. Watanabe, K. Oku, T. Nishimoto, M. Kubota, H. Chaen, S. Fukuda \& M. Kurimoto: Carbohydr. Res., 340, 1469 (2005).

15) K. Mukai, H. Watanabe, M. Kubota, H. Chaen, S. Fukuda \& M. Kurimoto: Appl. Environ. Microbiol., 72, 1065 (2006).

16) H. Watanabe, T. Nishimoto, T. Sonoda, M. Kubota, H. Chaen \& S. Fukuda: Carbohydr. Res., 341, 957 (2006).

17) H. Watanabe, T. Nishimoto, K. Mukai, M. Kubota, H. Chaen \& S. Fukuda: Biosci. Biotechnol. Biochem., 70, 1954 (2006).

18) H. Chaen, T. Yamamoto, T. Nishimoto, T. Nakada, S. Fukuda, T. Sugimoto, M. Kurimoto \& Y. Tsujisaka: J. Appl. Glycosci., 46, 423 (1999).

19) M. Kurimoto, A. Tabuchi, T. Mandai, T. Shibuya, H. Chaen, S. Fukuda, T. Sugimoto \& Y. Tsujisaka: Biosci. Biotechnol. Biochem., 61, 1146 (1997).

20) M. Kurimoto, T. Nishimoto, T. Nakada, H. Chaen, S. Fukuda \& Y. Tsujisaka: Biosci. Biotechnol. Biochem., 61, 699 (1997).

21) K. Maruta, H. Watanabe, T. Nishimoto, M. Kubota, H. Chaen, S. Fukuda, M. Kurimoto \& Y. Tsujisaka: J. Biosci. Bioeng., 101, 385 (2006).

22) 株式会社林原生物化学研究所 : 特開 2005-035958 (2005).

23) 株式会社林原生物化学研究所：特許第 4224302 (2002).

24) H. Aga, T. Higashiyama, H. Watanabe, T. Sonoda, T. Nishimoto, M. Kubota, S. Fukuda, M. Kurimoto \& Y. Tsujisaka: J. Biosci. Bioeng., 94, 336 (2002).
25) H. Aga, T. Higashiyama, H. Watanabe, T. Sonoda, R. Yuen, T. Nishimoto, M. Kubota, S. Fukuda, M. Kurimoto \& Y. Tsujisaka: J. Biosci. Bioeng., 98, 287 (2004).

26) P. Biely, V. Puchart \& G. L. Côté: Carbohydr. Res., 332, 299 (2001).

27) T. Shibuya, H. Aga, H. Watanabe, T. Sonoda, M. Kubota, S. Fukuda, M. Kurimoto \& Y. Tsujisaka: Biosci. Biotechnol. Biochem., 67, 1094 (2003).

28) H. Watanabe, H. Aga, T. Sonoda, M. Kubota, S. Fukuda, M. Kurimoto \& Y. Tsujisaka: Biosci. Biotechnol. Biochem., 67, 1182 (2003).

29) T. Higashiyama, H. Watanabe, H. Aga, T. Nishimoto, M. Kubota, S. Fukuda, M. Kurimoto \& Y. Tsujisaka: Carbohydr. Res., 339, 1603 (2004).

30) H. Watanabe, T. Higashiyama, H. Aga, T. Nishimoto, M. Kubota, S. Fukuda, M. Kurimoto \& Y. Tsujisak: Carbohydr. Res., 340, 449 (2005).

31) C. A. Dunlap, G. L. Côté \& F. A. Momany: Carbohydr. Res., 338, 2367 (2003).

32) 株式会社力ネカ, 株式会社林原生物化学研究所: 特開 2007-99902 (2007).

33) 株式会社力ネカ, 株式会社林原生物化学研究所：特開 2007-99903 (2007).

34) チッソ株式会社, 株式会社林原生物化学研究所：特許 5084008 (2006).

35) 株式会社カネカ, 株式会社林原生物化学研究所：特許 5126832 (2006)

36) 株式会社林原生物化学研究所, チッソ株式会社：特許 5650882 (2008).

37) C. Yang, W. Liang, M. Nishijima, G. Fukuhara, T. Mori, H. Hiramatsu, Y. Dan-oh, K. Tsujimoto \& Y. Inou: Chirality, 24, 921 (2012).

38) G. Fukuhara, T. Nakamura, Y. Kawanami, C. Yang, T. Mori, H. Hiramatsu, Y. Dan-oh, T. Nishimoto, K. Tsujimoto \& Y. Inoue: J. Org. Chem., 78, 10996 (2013).

39) X. Wei, W. Liang, W. Wu, C. Yang, F. Trotta, F. Caldera, A. Mele, T. Nishimoto \& Y. Inoue: Org. Biomol. Chem., 13, 2905 (2015).

40) F. Caldera, M. Argenziano, F. Trotta, C. Dianzani, L. Gigliotti, M. Tannous, L. Pastero, D. Aquilano, T. Nishimoto, T. Higashiyama et al.: Carbohydr. Polym., 194, 111 (2018).

41) T. Hashimoto, M. Kurose, K. Oku, T. Nishimoto, H. Chaen, S. Fukuda \& Y. Tsujisaka: J. Appl. Glycosci., 53, 233 (2006).

42) K. Hino, M. Kurose, T. Sakurai, S. Inoue, K. Oku, H. Chaen, K. Kohno \& S. Fukuda: Biosci. Biotechnol. Biochem., 70, 2481 (2006).

43）株式会社林原：国際公開特許WO/2018/173653 (2018).

44) 株式会社林原生物化学研究所, 株式会社大塚製薬工場 : 特開2011-256111 (2008).

45) T. Tagami, E. Miyano, J. Sadahiro, M. Okuyama, T. Iwasaki \& A. Kimura: J. Biol. Chem., 291, 16438 (2016).

46) Y. K. Kim, M. Kitaoka, K. Hayashi, C. H. Kim \& G. L. Côté: Carbohydr. Res., 339, 1179 (2004).

47) S. H. Light, L. A. Cahoon, A. S. Halavaty, N. E. Freitag \& W. F. Anderson: Nat. Microbiol., 2, 16202 (2016).

48) S. H. Light, L. A. Cahoon, K. V. Mahasenan, M. Lee, B. Boggess, A. S. Halavaty, S. Mobashery, N. E. Freitag \& W. F. Anderson: Structure, 25, 295 (2017).

49) 株式会社林原：特許第5923633 (2015).

50) T. Mori, T. Nishimoto, T. Okura, H. Chaen \& S. Fukuda: 
Biosci. Biotechnol. Biochem., 72, 1673 (2008).

51) T. Mori, T. Nishimoto, T. Okura, H. Chaen \& S. Fukuda: J. Appl. Glycosci., 58, 39 (2011).

52) M. Kohno, T. Arakawa, H. Ota, T. Mori, T. Nishimoto \& S. Fushinobu: J. Biol. Chem., 293, 16874 (2018).

53) T. Imanaka \& T. Kuriki: J. Bacteriol., 171, 369 (1989).

54) H. Takata, T. Kuriki, S. Okada, Y. Takesada, M. Iizuka, N. Minamiura \& T. Imanaka: J. Biol. Chem., 267, 18447 (1992).

55) H. Watanabe, T. Nishimoto, M. Kubota, H. Chaen \& S. Fukuda: Biosci. Biotechnol. Biochem., 70, 2690 (2006).

56) S. Janeček \& A. Kuchtová: FEBS Lett., 586, 3360 (2012).

57) L. S. Guidolin, A. E. Ciocchini, N. Iñón de Iannino \& R. A. Ugalde: J. Bacteriol., 191, 1230 (2009).

58) J. Vasur, R. Kawai, K. H. M. Jonsson, G. Widmalm, A. Engström, M. Frank, E. Andersson, H. Hansson, Z. Forsberg, K. Igarashi et al.: J. Am. Chem. Soc., 132, 1724 (2010).
プロフィール

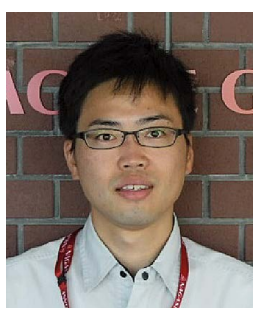

河野 正樹（Masaki KOHNO）

<略歴 $>2011$ 年大阪府立大学生命環境科学 部生物情報科学科卒業 / 2013 年同学大学院 生命環境科学研究科応用生命科学専攻修士 課程修了／同年株式会社林原入社／2018年 東京大学大学院農学生命科学研究科応用生 命工学専攻社会人博士課程修了（農学博 士), 現在に至るく研究テーマと抱負 $>$ 土 壤からの有用微生物ならびに酵素の探索, 新規糖質素材の開発＜ウェブサイト $><$ 趣 味>サッカー観戦（林原はファジアーノ岡 山を応援しています)

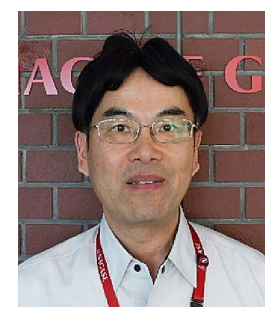

森哲也 (Tetsuya MORI)

<略歴>1989年九州大学農学部食糧化学 工学科卒業 / 1991年同大学大学院農学研 究科遺伝子資源工学専攻修士課程修了 / 同 年株式会社林原入社 $/ 2008$ 年広島大学大 学院生物圈科学研究科生物資源開発学専攻 博士課程修了 (博士 (農学)), 現在に至る <研究テーマと抱負 $>$ 糖質関連酵素の工業 生産<趣味>ネット上での世界遺産巡り

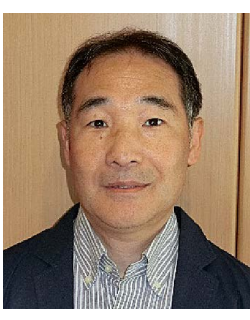

西本 友之 (Tomoyuki NISHIMOTO)

<略歴>1985年大阪府立大学農学部農芸 化学科卒業/1987年同大学大学院農学研 究科修士課程修了/同年株式会社林原入 社/1998年 博士(農学), 現在に至る <研究テーマと抱負 > 微生物トレジャーハ ンター, 澱粉に作用する酵素を極める<趣 味>テニス (実践\&観戦), 食料品売り場 のリサーチ

Copyright (C) 2019 公益社団法人日本農芸化学会 DOI: 10.1271/kagakutoseibutsu.57.679 